\section{В.С. Матющенко}

ФГБОУ ВО Амурская ГМА Минздрава России

г. Благовещенск

НАТУРАЛИСТИЧЕСКИЙ ПЕРИОД В РАЗВИТИИ ГРЕЧЕСКОЙ ФИЛОСОФИИ МЕДИЦИНЫ

Философия выражает уникальный опыт той культуры, на которой она произросла. В развитии философской мысли и философии как системы выделяют определенные этапы. Первым этапом в возникновении и развитии истории философии является античная философия. В данный период оформились основные философские учения и идеи. В период античности философия являлась основной наукой, предметом ее изучения был весь окружающий мир, всеобщее в системе мир-человек. По этой причине философы античности являлись так же государственными деятелями, астрономами, математиками и, зачастую, врачами. Философские учения оказывают значительное влияние на становление античной медицины и на формирование основных медицинских школ и направлений. В VI - V вв. до н.э. существовали две крупные медицинские школы - киренская и кротонская. Во времена Гиппократа существовали две соперничающие между собой медицинские школы - косская и книдская.

В истории античной философии можно выделить три основных этапа. К первому относятся милетская школа (Гераклит), а также элейская школа (философия периода VI-V вв. до н.э.). Второй этап (VIV вв. до н.э.) развития древнегреческой философии связан с именами мыслителей Сократ, Платон, Аристотель, школой атомистов (Левкипп, Демокрит), софистами (Протагор, Горгий). К третьему этапу эллинистической философии - относятся три главных течения: скептицизм, эпикуреизм и стоицизм (IV-III вв. до н.э.). В данной статье рассмотрим первый этап развития античной философии.

В Древней Греции первые философские учения возникли на о. Ион и были названы ионическими. На рубеже VII-VI вв. до н.э. в городе Милете появляется Милетская школа, с ней связаны имена трех мыслителей - Фалеса, Анаксимандра и Анаксимена. Их философские искания были направлены на то, чтобы найти первовещество из которого состоят все конкретные вещи реального мира. Это была натурфилософия. Натурфилософия (от лат. natura - природа) - философия природы, умозрительное истолкование природы, рассматриваемой в её целостности. Натурфилософию в дальнейшем сменило естествознание.

Фалес (конец VII - первая половина VI в. до н.э.) - основатель милетской школы, один из первых выдающихся греческих ученых и философов. С точки зрения Фалеса первоначалом всего является вода. Вода - разумное, аморфное, текущее сосредоточение материи. В этой «бесконечной воде» содержится потенция дальнейшего развития. Все остальное возникает путем «сгущения» или "разрежения» этой первоматерии. Вода изменчива, вслед за ее изменениями меняется наш мир. Фалес считал, что мир населен богами. Все вещи и явления, окружающие нас, имеют душу. Душу имеет и человек - это вода.

Анаксимандр (611-546 гг. до н.э.) был учеником Фалеса. Он поднялся на абстрактный уровень мышления и вывел термин апейрон - как первоначало, отличное от имеющихся субстанций. Анаксимандр учил: "Начало и основа всего сущего - апейрон». Апейрон означает «беспредельный, безграничный, бесконечный». Он характеризуется как нечто неопределенное, неограниченное не только в пространственном, но и во временном отношении, он материален и вещественен, вечен, вечно активен, атрибут апейрона - движение. Из него все состоит и все возникает. Апейрон сам все из себя производит.

Анаксимен (585-524 гг. до н.э.) - был учеником и последователем Анаксимандра. Философ считал, что основа бытия - неограниченный, бесконечный, имеющий неопределенную форму воздух. Беспредельность (апейрон) - его главное свойство. Из воздуха возникает весь мир, все вещи и явления в нем. Разрежение воздуха приводит к возникновению огня, а сгущение вызывает ветры, тучи, воду, землю и камни. С точки зрения Анаксимена, земля плоская, поддерживается воздухом. Испарения от земли разряжаются в огонь, части его, сжатые воздухом, образуют звезды. Допускал смену образования и разрушения мира. Анаксимен полагал, что душа человека так же воздушна.

B VI - V вв. до н.э. существовали две крупные медицинские школы - киренская и кротонская. Основоположником последней был Пифагор. В перечне десяти самых известных врачей $\mathrm{V}$ в. до н.э. названы исключительно пифагорейцы, среди которых Демокед, Каллифонт, Алкмеон из Кротона, Иккос из Тарента, Эмпедокл из Агригента и др.

Пифагорейская школа была основана Пифагором (род. 580-570 гг. до н.э.). Он первым назвал философию этим именем, а началом ее полагал числа и заключенные в них соразмерности (гармонии). Числа заключают в себе тайну вещей, а всемирная гармония есть совершенное выражение Бога. В школе Пифагора жизнь должна была содействовать очищению души и тела, которое достигалось правильной гигиеной и строгой дисциплиной нравов. В этой школе чередовались занятия гимнастикой и медициной, музыкой и науками. Пифагор называл своих учеников "математиками», т.к. обучение

Резюме В античной философии впервые NATURALIST PERIOD IN THE DEVELOPMENT OF GREEK PHILOSOPHY выкристаллизовались практически все OF MEDICINE главные философские проблемы, были V.S. Matyushchenko сформированы основные представления о FSBEI HE the Amur state medical Academy of Ministry of Public предмете философии, которые во многом Health of Russia, Blagoveshchensk

повлияли на последующие философские Abstract In ancient philosophy, almost all the main philosophical и медицинские концепции. Идеи древних problems crystallized for the first time, basic ideas about the subject философов оказали большое влияние на of philosophy were formed, which in many respects influenced становление и развитие медицины. subsequent philosophical and medical concepts. The ideas of Ключевые слова: философия, история аncient philosophers had a great influence on the formation and философии, история медицины, медицина, development of medicine.

косская школа, книдская школа.

Key words: philosophy, history of philosophy, history of medicine, medicine, school of cos, Cnidus school.

DOI 10.22448/AMJ.2018.3.66-68 
начиналось с учения о числах. Священная математика была у него наукой принципов, в которой числа есть сущность вещей. Число у Пифагора - не абстрактное количество, а существенное и деятельное качество верховной Единицы, т.е. Бога, источника мировой гармонии. Наука чисел была наукой живых сил, божественных качеств в действии: и в мирах (макрокосме), и в человеке (микрокосме).

Одно из главных изречений Пифагора, определившее в том числе и его методы лечения, звучит так: «Любым способом следует избегать и отсекать огнём, железом, всеми доступными средствами от тела - болезнь, от души - невежество, от желудка - излишество, от дома - разногласие, от всего в целом - неумеренность».

Путь к здоровой и добродетельной жизни Пифагор советовал начинать с правильного питания, ибо каждый продукт питания порождает свойственное лишь этому продукту состояние души, именно поэтому нельзя есть пищу, во-первых, чуждую богам (мясо, вино), и, во-вторых, священную (мальва и бобы). Пифагорейцы не рекомендовали употреблять в большом количестве любые мясные продукты, поскольку они мешают предвидению будущего, чистоте души и ясности сновидений.

Пифагор советовал своим ученикам диету Геркулеса, рецепт которой ему дала богиня Церера. Диета состоит из равных частей мака и кунжута, шкурок морского лука, из которого выдавливается сок, цветков нарцисса, листьев мальвы, ячменя и гороха, дикого меда. В питье следует использовать семена огурцов, изюм без косточек, цветы кориандра, семена мальвы и портулака, тертый сыр, молоко и масло, смешанные вместе и услащенные диким медом. При лечении людей от самых разных заболеваний пифагорейцы использовали травы и знали огромное количество очень эффективных рецептов. Пифагор и его ученики значительно чаще своих предшественников применяли целебные мази, а излюбленным методом лечения были припарки. Пифагор противился хирургии, т.к. не допускал изменения человеческого тела, данного творцом.

Пифагор, составивший гармонический ряд и заложивший основы музыкальной грамоты, придавал огромное значение использованию музыки для лечения. Гармония музыкальных вибраций, по его мнению, благотворно влияет на весь организм человека, успокаивает его нервы, поднимает настроение и через психику воздействует на внутренние органы. Пифагор делил музыкуна тритипа. Первый - самый низкий, примитивный вид - музыка для ног. Такую музыку воспроизводят инструменты для отбивания ритма: барабаны, ударники, басовые и погремушечные. Ритм заставляет сокращаться мышцы ног, рук, возбуждает первую и вторую чакры, а с ними пробуждает и все низменные инстинкты человека: агрессию, похоть, алчность, стремление властвовать. Вторая по важности - музыка струнных инструментов. Bce струнные, играющие гармоничные мелодии, воздействуют на сердечную чакру, на подсознание, на чувства людей. Иначе говоря, струнные инструменты, играя "классику», "лечат» душу. Самую важную для человека музыку дают духовые инструменты. Именно духовые инструменты, "работая» с духом человека, поднимают его на новую ступень развития, делая его ближе к Творцу. Однако, по мнению Пифагора, прослушивание божественных мелодий не просто наслаждение, а ментальная работа: к каждой теме, к каждой ноте слушатель должен создавать в своём воображении движущийся мыслеобраз, окрашивая его светом сердца. Только в этом случае музыка будет работать на созидание, а не на разрушение.

Пифагором был разработан метод лечения сменой цветового мысленного экрана. Если человек закроет глаза, то перед его мысленным взором появляется экран. У разных людей - разный. Чаще серый, темный, светлый, голубой, зеленый, красный, Амурский медицинский журнал №3 (23) 2018 с цветовыми пятнами, искрами и т.д. Далее Пифагор установил, что тёмные «экраны» сопутствуют подавленности, страху и нервному истощению, красный - патологическому перевозбуждению нервной системы, а нормой считался голубой и зелёный цвет, фиолетовый - цвет транса - обладает трансгенным свойством. Жёлтый и розовый вызывают чувство радости и повышают настроение, синий - вызывает мышечную релаксацию, серый цвет "экрана» делает психику пассивной и инертной и т.д. Зная о зависимости между цветом мысленного экрана и психофизиологией, Пифагор погружал пациента в транс и изменял ему цвет мысленного экрана в зависимости от заболевания. В комплексе с фитотерапией эта мера давала поразительный лечебный эффект.

Натурфилософия милетской школы сыграла важную роль не только в развитии философской мысли, но и в развитии современной ей греческой медицины. В частности, древнегреческий врач Алкмеон Кротонский (VI-V вв. до н.э.), пользуясь учением Анаксимена о воздухе как первооснове и первоисточнике всего существующего, создал «пневматическую систему медицины». Кроме того, Алкмеон впервые в истории медицины представил организм как единство противоположностей (равновесие влажного и сухого, холодного и теплого и т.п.). Не с именем Гиппократа, как это принято всеми, а с именем Алкмеона следует связывать появление в медицине принципа «противоположное есть лекарство от противоположного», который лег в основу всех последующих медицинских школ (кроме гомеопатов).

Алкмеон из Кротона - самый известный из пифагорейских врачей и автор первого дошедшего до нас медицинского трактата. Алкмеон учил, что здоровье человека сохраняется при равновесии противоположных сил, среди которых назывались пары "влажное и сухое», "тёплое и холодное», «горькое и сладкое» и т.д. Превалирование одной из противоположностей является причиной болезни. Алкмеон был одним из первых врачей, занимавшихся анатомированием. Он обнаружил нервы и определил их основное функциональное назначение, открыл евстахиеву трубу, «переоткрытую» затем в XVI в. Ещё одно достижение пифагорейской медицины учение о критических днях, согласно которому кризис каждой болезни наступал в строго определённые критические дни. Эти дни отсчитывались от начала болезни и выражались нечётными числами. Учение о критических днях существовало в европейской медицине вплоть до XVII в. Разумеется, нельзя назвать пифагорейскую медицину научной в строгом смысле этого слова, но элементы научного подхода в ней, несомненно, присутствовали. Пифагорейская медицина вошла в число базовых компонент, из которых в XIX в. начала формироваться научная медицина.

Представитель книдской медицинской школы Эврифон поддержал идею Алкмеона об изономии противоположностей как основе здоровья человека, что равномерное смешение (краза) и расстройство этого смешения (дискразия) определяют его здоровье или болезнь. Кроме того, им были заложены основы гуморальной теории патогенеза (о том, что из всех влаг наибольшее значение в организме имеют "слизь» и «желчь») [1].

Элейская школа и Гераклит (V в. дон.э.). Одна из философских школ этого времени - элейская (по имени города Элея в Южной Италии). Она представлена философами: Парменидом, Ксенофаном и Зеноном.

Родоначальником элейской школы считают

Ксенофана (570- 478 гг. до н.э.). Впервые в истории философии он высказал мысль о том, что все боги плод людской фантазии, что люди изобрели богов по своему образу, приписав им свои физические черты и нравственные недостатки. Богам античности 
он противопоставил одного бога, который един с природой.

Примерно в то же время творил Гераклит (544483 гг. до н.э.) из Эфеса, так же оказавший большое влияние на дальнейшее развитие философии. Подобно милетцам Гераклит считал, что все возникло из некоего первоначала. Таковым, по его мнению, является огонь. Он наиболее подвижен, способен к изменению, представляет собой не только круговорот вещей, но и основной принцип образования жизни Вселенной, основу всех космических процессов. Гераклит узрел субстанциально-генетическое начало всего сущего в вечном и божественном огне. Из огня возникают космос, земля и все остальное. Космос не вечен, он сгорает. Огонь все объемлет и все рассудит. При этом Гераклит не проводит грань между материальным и нравственным. Огонь способен уничтожить телесный мир, но так же он может уничтожить и душу человека. Здесь основными функциями огня являются очищение и воздание.

Гераклит считается основателем диалектического учения. Логос Гераклита помимо указанного, есть еще и диалектический закон вселенной. Все в мире абсолютно изменчиво все течет, все изменяется. Знаменитое выражение Гераклита «В одну реку нельзя войти дважды» говорит о том, что мир находится в постоянной изменчивости, В постоянном развитии. Во вселенной происходит вечная борьба противоположностей.

В медицине Древней Греции, как и в философии, господствовал дух дискуссий и соперничества нескольких школ. Особенно популярны были школы в Киренах, Кротоне и Родосе, а затем в Книде и на острове Кос. Каждая школа представляла собой определенное не только практическое, но и теоретическое направление. Следовательно, сама структура развития медицины в Греции была диалектической. Противоречия, возникавшие между школами, побуждали к новым поискам практических средств и теоретических обоснований того или иного учения. Разный подход к пониманию соотношения общего, особенного и единичного, части и целого выразился в специфической ориентации отдельных школ.

В период античности натурфилософия в силу своего научного содержания являлась единственной философской и естественно-научной основой медицины. На основе именно натурфилософии в той или иной степени разрешается вопрос о природе человека и, следовательно, целый ряд других вопросов практики и теории медицины.

\section{Литература}

1. Философия медицины / Ю.Л. Шевченко и др. М.: ГЭОТАР-МЕД, 2004. 480.

2. Чанышев, А. Н. Философия Древнего мира / А. Н. Чанышев. М.: Высшая школа, 2001. 703 с.

3. Чикин С.Я. Врачи-философы. М.: Медицина, 1990. 384 с.

Статья поступила в редакцию 11.02.2018

\section{Координаты для связи}

Матющенко Виктория Сергеевна, к.ф.н., доцент кафедры гуманитарных наук ФГБОУ ВО Амурская ГМА Минздрава России. E-mail: v89246728625@yandex.ru.

Почтовый адрес ФГБОУ ВО Амурская ГМА Минздрава России: 675000, Благовещенск Амурской области, Горького, 95.

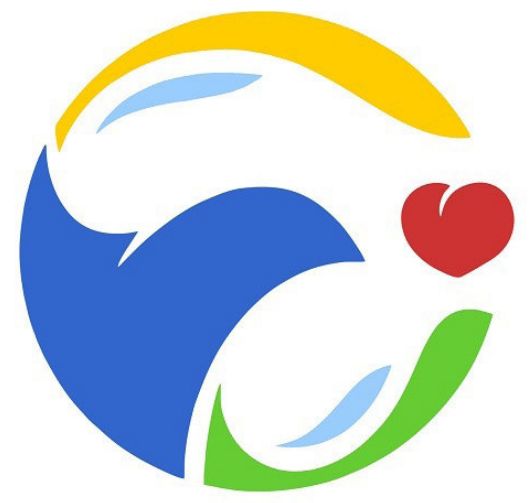

КУЛИКОВСКИЕ ЧТЕНИЯ 2018

научно-практическая конференция

«Стандарты, инновации и перспективы развития диагностики и лечения сердечно-сосудистых заболеваний»

22-23 июня 2018 года в Благовещенске прошла первая научно-практическая конференция «Куликовские чтения», посвященная профессору Я.П. Кулику, которому 16 мая исполнилось бы 90 лет.

Ярослав Петрович Кулик - основатель сердечнососудистой хирургии в Амурской области, организатор и руководитель Проблемной научноисследовательской лаборатории вспомогательного кровообращения с кардиохирургической клиникой при Благовещенском медицинском институте (ныне Клиника кардиохирургии Амурской государственной медицинской академии).

Организаторами конференции стали ФГБУ «Федеральный центр сердечно-сосудистой хирургии» Минздрава России (г. Хабаровск), ФГБОУ ВО «Дальневосточный ГМУ Минздрава России» (г. Хабаровск), ФГБОУ ВО «Тихоокеанский ГМУ Минздрава России» (г. Владивосток), ФГБОУ ВО «Амурская ГМА Минздрава России», Министерство здравоохранения Амурской области, Клиника кардиохирургии ФГБОУ ВО «Амурская ГМА Минздрава России» (г. Благовещенск).

\section{СЛОВО ОБ УЧИТЕЛЕ}

Я.П. Кулик (1928-2007) - потомственный врач, верный лучшим традициям земских медиков. В те годы, когда мало кто из советских врачей помышлял об операциях на открытом сердце, доктор Кулик отважился на их проведение в Смоленске. В дальнейшем он специализировался в клиниках Москвы, Ленинграда, Киева, Новосибирска, Чехословакии, Италии, Японии, ФРГ, Англии.

Основные направления научной деятельности Ярослава петровича: усовершенствование способов вспомогательного кровообращения при операциях 